\section{MAKNA PERTUNJUKAN DABUIH PADA \\ MASYARAKAT LUMPO PESISIR SELATAN SUMATERA BARAT}

\section{Yuniarti Munaf \\ FBS Universitas Negeri Padang}

$$
\text { Abstrak }
$$

The aims of this study are to know the functions of Dabuih performance in Lumpo of Pesisir Selatan Regency and its meanings. The analysis of meaning is focused on the supporting aspects, including stage and spectators. It is a qualitative research adopting an interaction symbolism. The informants, selected through the snowball sampling technique, were the village chief, Dabuih players, influential villagers, and spectators. The data were analyzed by using Spradley analysis model (1997). The validity was based on their credibility, transferability, dependability and conformability. The findings show that 1) Dabuih traditional art performance still exists and is preserved by Lumpo people. In its earlier development, Dabuih was a medium to introduce the Islamic teachings, but in the later development it was used as entertainment; 2) the meanings of Dabuih are related to religious and traditional aspects of the local people. To Dabuih viewers, the performance is religiously educative, integrative and entertaining media.

Key Words: the meanings of Dabuih, a performance in Lumpo

\section{A. Pendahuluan}

Pertunjukan dabuih (dabus) berkaitan dengan zikir secara berirama, yang isinya memuji-muji Allah serta salawat kepada Nabi Muhammad SAW dan para sahabatnya. Dabus juga berisikan nyanyian Islam berbentuk pantun yang diiringi dengan pukulan rebana (Boestami, 1981:3). Seni pertunjukan dabuih yang berlangsung di Nagari Lumpo berkaitan dengan zikir secara berirama yang dilagukan bersama-sama dengan kalimat la ilaha illallah mengikuti irama rebana disertai gerakan-gerakan tertentu seperti gerakan badan ke kiri dan kanan serta tangan dan kaki. Kondisi ini selanjutnya menghantarkan anggota dabuih sampak ke tingkat kekhusukan, di saat itu barulah dilakukan proses menusuk diri dengan senjata tajam.

Pertunjukan dabuih yang ada di Nagari Lumpo didukung oleh beberapa unsur antara lain; Khalifah, yaitu pemimpin pertunjukan dan pengendalian jalannya pertunjukan, anggota dabuih merangkap sebagai penabuh rebana, dan masyarakat penikmat (penonton). Perlengkapan yang disiapkan untuk kelangsungan pertunjukan, adalah; Aspek pendukung yang terdiri dari; paureh yaitu terdiri dari ramuan daun-daunan (sitawa, sidingin, cikarau, cikumpai, asam kapeh (jeruk nipis), dan beras tujuh butir. Ramuan (paureh) yang akan digunakan dalam proses pertunjukan, terutama untuk membasuh muka dan tangan para kebutuhan pasar kerja di tengah masyarakat dalam era teknologi dan komunikasi. Dengan demikian, kualifikasi yang diharapkan dari lulusan seni tari dapat memenuhi tuntutan-tuntutan kebutuhan di masyarakat sesuai dengan kebutuhan di era globalisasi.

Kurikulum Program Studi Pendidikan Seni Tari berbasis kompetensi disusun dengan mempertimbangkan kompetensi yang dibutuhkan masyarakat, sehingga kurikulum tersebut disusun harus mempertimbangkan pasar kerja berdasarkan kebutuhan stake holder, baik di bidang pendidikan (guru) maupun sanggar, grup-grup kesenian, entertainment, dan pariwisata.

Kurikulum berbasis kompetensi tahun 2002 ini akan selalu dikaji dengan mempertimbangkan kualifikasi lulusan setelah para lulusan terjun di masyarakat. Artinya, kurikulum akan selalu disesuaikan dengan kebutuhan pasar, kemampuan lulusan, dukungan serta mencari solusi pemecahan dari hambatan yang ada dalam pelaksanaan kurikulum.

\section{Karakteristik Kurikulum Pendidikan Seni Tari}

Dalam Kurikulum berbasis kompetensi tahun 2002 dilaksanakan mata kuliah common ground yang harus ditempuh mahasiswa, baik tingkat universitas, fakultas, jurusan, maupun program studi. Kurikulum Program Studi Pendidikan Seni Tari memberikan kemampuan kepada mahasiswa kewenangan bidang studi dengan beban studi 148 sks.

Kurikulum seni tari dengan beban studi 146 sks dikelompokkan menjadi 3 bagian yaitu: Mata Universiter, Mata Kuliah Fakulter, Mata Kuliah Jurusan, dan Mata Kuliah Program Studi. Pengelompokan tersebut dapat dibagi lagi menjadi kelompok-kelompok lebih kecil dan lebih spesifikasi lagi.

Pengelompokan mata kuliah dapat dibagi menjadi Universiter (24 sks), Fakulter (4 sks), Jurusan (2 sks), Dan Program Studi (118 sks). Adapun untuk kompetensi lulusan dibagi menjadi kelompok sebagai berikut: a) Pendidikan/Pengajaran (27 Sks), b) Pengkajian (36 Sks), c) Pengelolaan Usaha/Manajemen (8 Sks), d) Dasar untuk semua kompetensi (13) .Untuk elemen kompetensi dikelompokkan menjadi 5 yaitu: (a) Matakuliah Pengembang Kepribadian ada 12 Sks (8\%), (b) Matakuliah Keilmuan dan Ketrampilan ada 44 Sks (30 \%), (c) Matakuliah Keahlian Berkarya ada 60 Sks (41 \%), (d) Matakuliah Perilaku Berkarya ada 19 Sks (13 \%), dan Matakuliah Berkehidupan Bermasyarakat ada 13 Sks ( 8\%). Jenis Kompetensi dibedakan menjadi (a) Mata Kuliah Utama 81 Sks (55 \%), (b) Mata Kuliah penunjang 63 Sks ( 42\%), dan (c) Mata Kuliah Lain 4 Sks ( 3\%). Pembagian Mata kuliah Teori, Praktek, dan Lapangan dapat dikelompokkan menjadi (a) Mata Kuliah teori 78 Sks (53\%), Mata Kuliah Praktek 58 Sks (40\%), dan Mata Kuliah Lapangan 10 Sks (7 \%).

Mata kuliah Program Studi yang berjumlah 118 Sks, terdiri dari beberapa mata kuliah praktek tari dan teori. Oleh karena Universitas Negeri Yogyakarta secara geografis terletak di wilayah bekas kerajaan Mataram (Yogyakarta dan 
seperti perkawinan, sunatan dan sebagainya. Hal ini berlaku juga pada masyarakat Lumpo, yang hampir melupakan kesenian tradisi yang diwariskan oleh generasi sebelumnya. Tetapi sebagian kecil masyarakat Lumpo masih peduli terhadap kesenian dabuih, sehingga sampai saat ini kesenian dabuih masih tetap dipertahankan keberlangsungannya. Pertunjukan dabuih saat ini lebih berorientasi kepada seni tontonan yang berfungsi sebagai hiburan yang juga ditampilkan pada berbagai upacara seperti perkawinan, sunatan, pengangkatan penghulu dan pengangkatan wali nagari. Pertunjukan dabuih di samping berorientasi seni juga terkait dengan ritus seperti terlihat pada tahap awal pertunjukan pemakaian paureh dan kemenyan dalam proses pertunjukan.

Berdasarkan "grand tour" di Kenagarian Lumpo ada dua kelompok pertunjukan dabuih yaitu kelompok Jaya Bersama dan kelompok Maju Bersama. Kelompok pertunjukan dabuih ini ditampilkan apabila ada pesanan untuk hajatan perkawinan, sunatan dan helat nagari. Suatu hal yang menarik pada proses pertunjukan dabuih yaitu pada saat pemain menusuk-nusuk tubuh dengan besi runcing yang tajam dengan sekuat tenaga, tetapi tubuh pemain tidak luka dengan benda tersebut. Terkait dengan aspek pendukung seperti paureh, kemenyan putih yang digunakan untuk pertunjukan bermakna yang dapat memberikan pengaruh bagi proses melukai diri pada pertunjukan dabuih. Kemudian zikir dan doa yang dibaca khalifah pada saat pertunjukan juga bermakna yang ikut memberi pengaruh pada pertunjukan dabuih

Pada hakekatnya pertunjukan dabuih mengandung unsur religi dan seni, keduanya saling terkait dan melengkapi. Menurut pelaku seni, unsur religi dalam pertunjukan dabuih seperti doa yang dibaca oleh khalifah pada prosesi memercikan ramuan ke arena pertunjukan dapat menolak makhluk halus yang ingin mengganggu jalannya pertunjukan. Hal ini membuat daya tarik dari pertunjukan dabuih. Namun, untuk mempertahankan unsur religi ini bukanlah hal yang mudah,

karena terbatasnya minat dari generasi muda yang ingin mempelajari pertunjukan dabuih ini. Lebih menarik lagi pertunjukan dabuih tidak pernah ditinggalkan oleh masyarakat untuk digelar pada upacara pengangkatan penghulu dan pengangkatan wali nagari, walaupaun orgen tunggal juga dipagelarkan sehingga pertunjukan dabuih sangat bermakna bagi masyarakat.

Bertitik tolak dari fenomena tersebut, tentu amat penting diteliti bentuk pelaksanaan pertunjukan dabuih dan makna pertunjukan dabuih yang terdapat pada semua aspek pendukung pertunjukan yang berpengaruh pada proses melukai diri di saat dabuih dipertunjukan. Persoalan makna yang terkandung pada aspek pertunjukan dabuih menarik untuk ditelusuri melalui penelitian ini, apa makna yang terkandung pada paureh, kemenyan putih, dan anak dabuih. Kemudian makna zikir dan doa yang dibacakan khalifah pada tahapan indang berpengaruh terhadap proses pertunjukan. Selanjutnya bagaimana masyarakat memaknai pertunjukan dabuih, pengungkapan masalah tersebut bermanfaat terhadap
Bahwa hasil pendidikan beberapa cabang seni yang mungkin tidak angsung tampak untuk kemanfaatan praktis di kehidupan yang serba pragmatik ini, memang sebagian ada benarnya. Namun perlu diingat bahwa pendidikan seni lebih berfungsi pada proses pembentukan manusia sebagai manusia yang memiliki tuntutan kualitas kehidupan yang kompleks. Pendidikan seni adalah suatu investasi jangka panjang yang hasilnya tidak bisa langsung terlihat., namun dalam jangka panjang dapat membentuk manusia yang memiliki rasa keindahan, kreativitas, sensitivitas, kepedulian dan kepekaan sosial. Sekali lagi pertanyaan kita adalah : bagaimana kira-kira bentuk kehidupan di dunia ini tanpa adanya sentuhan seni, karena orang-orang sudah tidak punya lagi rasa keindahan? Dengan demikian, visi pendidikan tinggi yang masih menempatkan seni sebagai landasan pengembangan ilmu dan teknologi sangatlah tepat.

\section{Kurikulum Jurusan Pendidikan Seni Tari}

Seiring dengan gencarnya issue pentingnya kurikulum berbasis kompetensi, maka maka Jurusan Pendidikan Seni Tari memang harus memiliki kurikulum berbasis kompetensi yang relevan dan sesuai dengan kebutuhan pasar. Makin maraknya pengaruh budaya asing masuk di lingkungan generasi muda, dikhawatirkan sedikit demi sedikit akan mengikis seni budaya tradisi yang kita miliki. Salah satu tanggung jawab lembaga pendidikan adalah menyelenggarakan pendidikan seni (dalam pembahasan ini adalah seni tari) sebagai usaha untuk tetap menanamkan nilai-nilai seni budaya tradisi yang kita miliki sebagai kekayaan bangsa melalui out put-out put yang dihasilkan oleh Jurusan Pendidikan Seni Tari. Di samping itu, sejalan dengan dikembangkannya pariwisata, maka out put Program Studi Pendidikan Seni Tari masih banyak dibutuhkan untuk ikut melestarikan dan mengembangkan seni - khususnya seni tari - sebagai aset budaya untuk kepentingan pariwisata. Hal ini terbukti dengan banyaknya lulusan Program Studi Pendidikan Seni tari yang ikut terlibat dalam kegiatan pengembangan seni budaya dan pariwisata. Bahkan para mahasiswa yang belum lulus pun banyak terlibat dalam kegiatan tersebut

Lulusan pendidikan seni tari Universitas Negeri Yogyakarta secara de jure adalah menjadi guru tari. Kenyataan di atas membuktikan bahwa banyak lulusan pendidikan seni tari yang bekerja menjadi guru. Hal tersebut dikarenakan beberapa faktor yang salah satunya adalah pelaksanaan kurikulum di sekolah-sekolah menengan pertama (SLTP) dan SMU. Pelaksanaan kurikulum di pendidikan tingkat menengah tidak menempatkan pendidikan seni sebagai sesuatu yang penting, sehingga pendidikan seni yang dilaksanakan di sekolah menengah sangatlah minim. Dampak dari hal tersebut adalah banyak lulusan pendidikan seni tari yang tidak menekuni pekerjaan sebagai guru. Faktor yang lain seperti disebutkan di atas, semakin berkembangnya dunia pariwisata, memberi peluang para lulusan untuk memiliki profesi ganda menjadi guru atau seniman, atau menjadi guru dan seniman, bahkan pengelola suatu perusahaan entertainment. 
dabuih merupakan bentuk-bentuk simbolis perasaan manusia.

Dalam pertunjukan dabuih zikir-zikir yang dibaca memuji-muji Allah, sehingga para pemain sampai pada fana dalam berhubungan dengan Allah. Hamka dalam Arifin (1993:1) menjelaskan praktek menyakiti diri sendiri tersebut beserta keajaiban-keajaibannya menandakan bahwa murid itu sudah fana betul-betul dari sebab zikirnya kepada Allah, tidaklah ada perasaan lagi. Kemudian Snouck Hurgronye menyebutkan bahwa permainan Dabus dan rebana sangat rapat hubungannya dengan tarekat yang memiliki didikan ganjil dan menganggap sempurna dan keramat para penganutnya apabila telah dikaruniai oleh Tuhan dengan berbagai keajaiban, diantaranya kebal, tidak dimakan senjata tajam, tidak terbakar dalam api dan sebagainya.

Dadang Kahmad (2000:210) menjelaskan tarekat secara harfiah berarti jalan atau cara untuk mencapai tingkatan-tingkatan (maqamat) dalam rangka mendekatkan diri kepada Tuhan. Melalui cara ini seorang sufi dapat mencapai tujuan peleburan diri dengan nyata (fana fil al-haq). Mengikuti suatu tarekat berarti melakukan olah batin, latihan-latihan (riyadhah) dan perjuangan yang sungguhsungguh (mujahadah) di bidang kerohanian. Mengikuti suatu tarekat juga berarti membersihkan diri dari sifat mengagumi diri sendiri ('ujub), sombong (takabur), ingin dipuji orang (riya'), cinta damai, dan sifat-sifat negatif lainnya. Selain itu pengikut tarekat juga harus mengusahakan sikap ikhlas, rendah hati (tawadhu') berserah diri (tawakal) dan rela (ridha), dan sikap-sikap positif lainnya. Uraian di atas dapat dipakai untuk melihat hakekat dabuih dan proses pelaksanaan dabuih dalam masyarakat Lumpo, bagaimana para pemain dabuih sampai pada tingkat kefanaan atau ekstase, ataupun kerasukan (wajd).

\section{Pertunjukan Dabuih sebagai Kesenian Tradisi}

Sedyawati (1981:60) seni pertunjukan adalah sesuatu yang berlaku dalam waktu. Satu bentuk seni pertunjukan tradisional bisa mengikuti pola berulang dari segi keterampilan teknis, namun segi-segi lainnya selalu mengandung perubahan. Kemudian Richard Schechner dalam Murgianto, (1997:27) menjelaskan pertunjukan adalah sebuah proses yang memerlukan waktu dan ruang. Sebuah pertunjukan mempunyai bagian awal, tengah dan akhir. Sedangkan struktur dasar pertunjukan mempunyai tahapan : (1) persiapan bagi pemain maupun penonton, (2) pementasan/pelaksanaan, (3) apa-apa yang terjadi setelah selesai pertunjukan. Sejalan dengan hal tersebut, dalam pelaksanaan dabuih selalu terkait dengan aspekaspek ritual: (1) persiapan air yang berisi ramuan jeruk nipis dan tumbuhan lainnya, (2) beras, (3) sebuah pisau tajam, (4) kemenyan, dan (5) bara api (Yusfil, 1991:2).

Lebih jauh Sedyawati (1981:62) menjelaskan bahwa seni pertunjukan adalah sesuatu yang membutuhkan kelompok dan memberikan sesuatu pengalaman langsung kepada penikmat. Seni pertunjukan mempunyai nilai sebagai penikmatan, yang terwujud sebagai pengalaman yang berisi pembayangan manusia yang beriman dan bertakwa terhadap Tuhan Yang Maha esa, berbudi pekerti luhur, sehat jasmani dan rohani, berkepribadian yang mantap dan mandiri serta mempunyai rasa tanggung jawab kemasyarakatan dan kebangsaan. Kemampuan lain secara khusus yang dimiliki tamatan adalah sesuai dengan program studinya yaitu memiliki kompetansi di bidang seni tari.

Kemampuan lulusan SMK Program Studi Seni Tari dapat dibagi menjadi 4 bagian dengan masing-masing sub kemampuan (GBPP Buku IIA, Depdikbud, 1993:3):

I. Mampu menarikan berbagai repertoar tari bentuk:

a. Melaksanakan teknik olah tubuh

b. Memperagakan teknik olah tubuh

c. Mengolah irama gerak tari

d. Memperagakan teknik penguasaan tari bentuk

e. Memainkan instrumen iringan tari tertentu

f. Memainkan instrumen musik dan bernyanyi

II. Mampu melaksanakan pertunjukan:

a. Melaksanakan tata teknik pentas

b. Mngelola usaha seni pertunjukan

c. Melaksanakan produksi seni tari

III. Mengelola Usaha Seni Tari:

a. Mengelola usaha seni pertunjukan

b. Menguasai wawasan seni budaya

c. Melaksanakan produksi seni tari

IV. Melatih tari :

a. Menguasai perbendaharaan tari bentuk

b. Menerapkan metode praktis pelatihan tari.

Dilihat dari deskripsi mata pelajaran yang ada dalam GBPP, terdapat mata pelajaran yang terbagi menjadi 2 program, yaitu program umum terdiri dari 5 mata pelajaran (Pendidikan Pancasila dan Kewarganegaraan, Pendidikan Agama, Bahasa dan Sastra Indonesia, serta Sejarah Nasional dan Sejarah Umum. Kedua program kejuruan yang menyangkut kemampuan bidang studi yaitu terdiri dari 15 mata pelajaran: Matematika, Bahasa Inggris, Pengelolaan Usaha dan Pementasan, Wawasan Seni Budaya, Praktek Seni Tari, Penunjang Seni Tari, Musik, Tata Teknik Pentas, Sastra Tari, dan Pengalaman Kerja Lapangan. Semua mata pelajaran dilaksanakan dalam 2 semester. Dari uraian tersebut dapat dilihat bahwa kompetensi lulusan SMK Program Studi Seni Tari mampu dan menguasai bidangbidang yang terkait dengan seni pertunjukan, dan di samping itu juga memahami tentang kewirausahaan.

Sekolah Menengah Kejuruan Seni Pertunjukan adalah SMK yang mempunyai karakteristik tersendiri artinya SMK Seni Pertunjukan mempunyai karakter yang berbeda dengan SMK lainnya (seperti teknik, kimia, dsb). Hal 
Cassirer (1987:294) menjelaskan manusia makhluk yang penuh dengan simbol (lambang). Melalui simbol atau lambang seluruh budaya manusia dapat diungkap, yang perlu ditangkap adalah makna dari suatu benda tertentu. Kebudayaan sebagai wadah yang memuat pengalaman serta pengetahuan manusia secara keseluruhan diturunkan dan diajarkan dari generasi ke generasi berikutnya melalui sistem simboliknya. Esensi simbolisme terletak dalam pengakuan sesuatu sebagai pengganti sesuatu yang lain, bisa dalam bentuk konkrit maupun abstrak. Simbol itu sendiri muncul dengan kekuatan tersendiri untuk melindungi objek (sasaran), seperti, pembakaran kemenyan dan air paureh yang disebarkan di sekeliling tempat pertunjukan dan untuk paureh para pemain dabuih, dapat merupakan ungkapan simbolik untuk memohon kepada Yang Maha Kuasa. Simbol digunakan dalam bentuk ungkapan kata, benda, kesenian atau lambanglambang tertentu, guna mengekspresikan makna yang melekat dan terkait dalam setiap kejadian hidup secara luas dan intensif. Untuk memahami makna dari simbol harus dirujuk pada lingkungan dimana terkait.

Dapat disimpulkan bahwa material apapun bentuknya dapat memberi makna dari simbol-simbol melalui benda-benda, gambar dan tulisan, sehingga dapat memberikan suatu komunikasi baik verbal maupun visual. Pertunjukan dabuih yang didukung oleh beberapa aspek pendukung, seperti paureh, kemenyan merupakan simbol yang mengandung nilai-nilai yang dapat dijadikan media komunikasi, dan visual dari pesan simbol yang terkandung di dalamnya. 4. Seni dan Ritus Dabuih

Pertunjukan dabuih merupakan seni pertunjukan yang dipadukan dengan musik rebana dan gerakan tari sederhana yang menghantarkan pemain pada tahap kekhusukan, hal ini mempunyai makna bagi pendukung. Koentjaraningrat (1985:25) seni merupakan satu unsur kebudayaan dan aktivitas manusia yang bermuatan nilai, norma, serta estetika yang terbentuk akibat adanya pola hubungan antara individu dan kelompok dalam masyarakat.

M. Yunus (1997:5) menjelaskan unsur-unsur seni diantaranya indah, halus, kreatif, melancholis, harmoni, kebenaran, kompetitif, riang, disiplin, dinamis, taqwa, tertib dan waspada. Menurut Gie dalam Sujarwa, (1999:53) bahwa nilai seni (keindahan) memiliki kecenderungan untuk mengisyaratkan suatu "pesan makna" yang berkaitan dengan filsafat hidup, budaya dan psikologi. Lebih lanjut Soedarsono (1985:18) menjelaskan fungsi seni dalam kehidupan manusia adalah: 1) sarana upacara, (2) hiburan, dan (3) tontonan.

Pada pertunjukan dabuih unsur-unsur pendukung yang dipakai seperti kemenyan dan paureh memiliki pesan makna yang berkaitan dengan budaya dipakai dalam kehidupan, intinya simbol dari unsur tersebut bermakna permohonan perlindungan kepada Yang Maha Kuasa dalam melakukan pertunjukan. terbuka lebar kesempatan bagi lulusan SMK untuk dapat mengembangkan kemampuannya pada level pendidikan yang lebih tinggi.

Untuk mengkaitkan antara program studi seni tari di Sekolah Menengah Kejuruan dengan Jurusan Pendidikan Seni Tari di perguruan tinggi, maka harus dilihat terlebih dahulu sejauh mana kurikulum yang berlaku di SMK Seni Pertunjukan khususnya Program Studi Seni Tari. Bagaimanakah karakteristik kurikulum SMK Seni Pertunjukan? Bagaimanakah karakteristik instrumental input di perguruan tinggi? Bagaimanakah interfacing antara kurikulum SMK dengan kurikulum di pendidikan tinggi?

Untuk menjawab semua pertanyaan itu, maka perlu disinggung tentang: 1) keterkaitan (interfacing) antara kompetensi dalam kurikulum SMK Seni Pertunjukan (Seni Tari) dengan kompetensi dalam kurikulum perguruan tinggi yang menyelenggarakan pendidikan seni (Jurusan Pendidikan Seni Tari); 2) keterkaitan (interfacing) antara karakteristik kurikulum SMK dengan karakteristik perguruan tinggi (Jurusan Pendidikan Seni Tari); dan 3) keterkaitan (interfacing) antara karakteristik instrumental input SMK dengan karakteristik instrumental input di perguruan tinggi.

C. Pendidikan Seni Tari Sekolah Menengah Kejuruan

Secara sistematik, pendidikan kejuruan merupakan subsistem dari sistem pendidikan. Banyak definisi yang diajukan oleh para ahli tentang pendidikan kejuruan dan beberapa definisi tersebut berkembang seirama dengan persepsi dan harapan masyarakat tentang peran yang harus dimainkan. Dari definisi tersebut terdapat satu pengertian yang bersifat universal seperti yang dinyatakan oleh National Council for Research into Vocational Education (NCRVE,1981, Kir Haryana, 2000), bahwa pendidikan kejuruan merupakan sub sistem pendidikan yang secara khusus membantu peserta didik dalam mempersiapkan diri memasuki lapangan kerja. Dari batasan tersebut dapat disimpulkan bahwa salah satu ciri pendidikan kejuruan dan yang sekaligus membedakannya dengan jenis pendidikan lain adalah orientasinya pada penyiapan peserta didik untuk memasuki lapangan kerja. Agak berbeda dengan definisi tadi, Finch dan Crunkilton (1979) menyebut bahwa pendidikan kejuruan sebagai pendidikan yang memberikan bekal kepada peserta didik untuk dapat bekerja guna menopang kehidupannya.

1. Tujuan Pendidikan Kejuruan

Pendidikan kejuruan diselenggarakan dengan tujuan untuk (1) memberikan bekal ketrampilan individual dan ketrampilan yang laku di masyarakat, sehingga peserta didik secara ekonomis dapat menopang kehidupannya, (2) membantu peserta didik memperoleh atau mempertahankan pekerjaan dengan jalan memberikan bekal ketrampilan yang berkaitan dengan pekerjaan yang diinginkannya, (3) mendorong produktivitas ekonomi secara regional maupun nasional, (4) mempersiapkan tenaga terlatih untuk menopang perkembangan ekonomi dan industri, dan (5) mendorong serta meningkatkan 


\section{Makna Pertunjukan Dabuih pada Tahapan Indang}

Pada proses pelaksanaan pertunjukan dabuih dibagi dengan beberapa tahapan indang, mulai dari indang pertama sampai pada indang ke tujuh. Masingmasing tahapan indang memiliki makna sesuai dengan proses indang tersebut. Pada indang pertama mengenai posisi duduk khalifah dan pemain dabuih terkandung makna bahwa dengan posisi duduk dengan pola lantai berbentuk leter $\mathrm{U}$ berarti melingkari arena pertunjukan supaya terhindar dari gangguan roh jahat yang ingin mengganggu jalannya pertunjukan. Kemudian makna dalam zikir pada tahapan indang pertama ini terkandung makna mohon ampunan kepada Allah dan mohon perlindungan dalam menggelar pertunjukan dabuih tersebut.

Selanjutnya pada tahapan indang ke dua terkandung makna ucapan salawat kepada junjungan umat Nabi Muhammad SAW, yang telah memberikan safaat kepada umatnya, bagaimana cara umatnya mencari jalan yang terang menuju Allah. Pada tahapan indang ke tiga terkandung makna bahwa dalam proses badabuih menggunakan anak dabuih sebagai aspek pendukung, dalam hal ini bagaimana pemain dabuih memohon kepada Allah supaya anak dabuih (besi) yang digunakan dalam permainan dapat bersahabat dengan tubuh dengan arti kata digunakan untuk menusuk tubuh tetapi tidak dapat melukai.

Kemudian pada tahapan indang ke empat terkandung makna juga permohonan kepada Allah, agar aspek pendukung paureh dapat menjadi obat perawat pada saat pertunjukan digelar dan anak dabuih dapat bersahabat dengan tubuh, kemudian kalau terjadi luka dapat dipertemukan kembali dagingnya dengan air paureh. Pada indang ke lima terkandung makna mengusir makhluk halus atau jin dari arena pertunjukan supaya ia tidak mengganggu jalannya pertunjukan dabuih, kemudian juga memohon perlindungan kepada Allah dalam proses melukai diri dengan senjata tajam.

Pada tahapan indang ke enam dan ke tujuh terkandung makna bahwa Allah adalah raja, raja sekalian alam. Allah satu, kepada dia-Nya tempat meminta perlindungan. Walaupun besi yang dibawa melompat-lompat dan mengenai punggung, tetapi ia tidak akan melukai. Karena ia dalam pandangan mistik bisa bersahabat dengan tubuh. Sejalan dengan hal ini, Dadang Kahmad (2000:206) menjelaskan bahwa setiap agama memiliki potensi untuk melahirkan bentuk keagamaan yang bersifat mistik. Inti sarinya adalah kesadaran akan adanya komunikasi rohaniah antara manusia dengan Tuhan. Kemudian Simuh (1984) mengatakan bahwa debus merupakan bagian dari mistik, yaitu suatu kepercayaan bahwa manusia dapat mengadakan komunikasi langsung dengan Tuhan melalui tanggapan batin di dalam meditasi. Terkait dengan persoalan tahapan indang dalam pertunjukan dabuih bahwa kekuatan lahiriyah dapat dilihat dari metode zikir yang dipadukan dengan nyanyian religius yang dipandu dengan pukulan rebana yang menghasilkan musik yang harmonis.

Selanjutnya Imron Arifin menjelaskan dengan metode zikir dapat pertunjukan, yaitu ISI Yogyakarta, yang menghasilkan seniman di bidang seni tari, dan Universitas Negeri Yogyakarta, yang menghasilkan guru seni tari.

Kedua perguruan tinggi yang menyelenggarakan pendidikan seni tari mememiliki kurikulum yang muatannya sejenis dengan kurikulum yang ada di SMK Seni Pertunjukan. Perbedaan yang ada di antara keduanya adalah di ISI Yogyakarta kurikulumnya memberikan pengembangan ilmu murni di bidang seni tari, sedangkan di Universitas Negeri Yogyakarta yang memiliki Program Studi Pendidikan Seni Tari, di samping memuat mata kuliah ilmu murni bidang seni tari, juga memiliki muatan mata kuliah keguruan dan kependidikan untuk memberi bekal mahasiswa sebagai calon guru/pendidik di bidang seni tari.

Universitas Negeri Yogyakarta memiliki Jurusan Pendidikan Seni Tari dengan Program Studi Pendidikan Seni Tari. Program Studi Pendidikan Seni Tari menerima input dari berbagai sekolah, baik dari sekolah umum maupun kejuruan. Dengan demikian, input yang masuk bersifat heterogen, artinya input berasal dari Sekolah Menengah Kejuruan Seni Pertunjukan - yang memiliki Program Studi Seni Tari - dan dari Sekolah Menengah Umum. Oleh karena itu, kemampuan awal yang dimiliki oleh mahasiswa sangat bervariasi. Muatan kurikulum yang dilaksanakan di Program Studi Pendidikan Seni Tari FBS UNY disusun dengan mempertimbangkan kondisi input yang bervariasi tersebut, sehingga kurikulum yang ada di Program Studi Pendidikan Seni Tari diberlakukan secara umum artinya input dari SMK Seni Pertunjukan diperlakukan sama dengan input dari SMA yang belum mendapatkan kemampuan-kemampuan yang dimiliki oleh input dari SMK Seni Pertunjukan.

Melihat kenyataan di atas, tampak adanya ketidak efisienan dalam penyelenggaraan pendidikan seni tari di perguruan tinggi khususnya bagi input yang berasal dari SMK Seni Pertunjukan. Apabila dilihat dari muatan kurikulum, maka terjadi pemborosan waktu studi di semester-semester awal bagi mahasiswa yang berasal dari SMK Seni Pertunjukan.

Prinsip efisiensi dengan mempertimbangkan input yang ada merupakan salah satu solusi yang perlu dikaji dalam pemecahan masalah tersebut. Efisiensi yang dimaksud adalah dengan mengkaji potensi yang dimiliki oleh input yang berasal dari sekolah-sekolah kejuruan seni pertunjukan. Dengan demikian, input dari sekolah kejuruan seni pertunjukan yang natabene memiliki "kemampuan lebih" dibandingkan input dari sekolah menengah umum, akan mendapat perlakuan berbeda secara formal, misalnya dengan mendapat previlage dari lembaga pendidikan tinggi penyelenggara. Hal tersebut akan mempersingkat masa studi mahasiswa.

Makalah ini akan membahas kemungkinan-kemungkinan yang dapat dikembangkan dalam penyelenggaraan proses belajar mengajar di perguruan tinggi yang menyelenggarakan pendidikan seni atau yang memiliki jurusan atau program studi yang sama dengan sekolah kejuruan. Apakah keterkaitan 
Ke empat, pertunjukan dabuih dimaknai syarat dengan berbagai persoalan mistik seperti paureh, kemenyan yang merupakan perlengkapan yang menjadi keharusan dalam pertunjukan dabuih. Kahmad (2000:26) menjelaskan inti sari dari mistik (mistisme) adalah kesadaran akan adanya komunikasi rohaniah antara manusia dengan Tuhan. Ke lima, pertunjukan dabuih dimaknai lebih berorientasi hiburan, sarana integratif yang dapat menumbuhkan rasa kebersamaan yang mengikat di antara pendukungnya. Ke enam, pertunjukan dabuih dimaknai mengukuhkan nilai-nilai budaya yang diambil oleh masyarakatnya. Selanjutnya ia dimaknai merupakan aktivitas relio-mistis, awalnya dalam bentuk pertunjukan seni di kalangan pengajian tarekat. Lebih lanjut masyarakat juga memaknai pertunjukan dabuih sebagai pertunjukan seni bernuansa Islam, sebagai sarana dakwah, karena syair-syairnya terkait dengan nilai-nilai ibadah.

\section{Penutup}

\section{Simpulan}

Pertunjukan dabuih merupakan seni pertunjukan tradisi yang masih tetap eksis dalam kehidupan masyarakat Lumpo yang pada mulanya merupakan kesenian anak nagari yang dianggap sakral, dewasa ini pertunjukan dabuih lebih mengarah kepada seni yang bersifat entertainment (hiburan) yang mempertontonkan kekebalan tubuh, dan dalam pelaksanaannya ada unsur ritus. Pelaksanaan pertunjukan dabuih pada masyarakat Lumpo ini digelar pada upacara perkawinan, sunatan, pengangkatan penghulu dan pengangkatan wali nagari. Pembacaan zikir secara berirama yang dipandu dengan pukulan rebana bersinkretis dengan doa, sehingga dapat mengantarkan pemain dabuih pada kondisi kekhusukan untuk melakukan proses menusuk tubuh dengan senjata tajam (badabuih)

Pertunjukan dabuih bermakna bagi masyarakat, terutama makna yan terkandung aspek pendukung yaitu paureh, kemenyan putih, anak dabuih dan penonton pertunjukan. Makna pertunjukan pada aspek pendukung dabuih merupakan lambang/simbol yang memiliki makna adat yang telah diterima secara turun temurun dari generasi sebelumnya seperti paureh memiliki simbo pendingin bagi anggota dabuih dan arena pertunjukan untuk penangkal orang yang ingin mencelakai pemain dabuih pada saat melakukan atraksi dabuih. Pada tahapan indang dalam pelaksanaan pertunjukan berkaitan dengan zikir yang bersinkretis dengan doa yang dibaca oleh khalifah dan pemain dabuih merupakan lambang/simbol yang mengandung makna religi berkaitan dengan permohonan perlindungan kepada Yang Maha Kuasa untuk melindung pemain terutama dalam hal atraksi menusuk tubuh dengan senjata tajam. Bagi masyarakat penikmat dari golongan remaja memaknai dabuih sebagai ilmu bela diri yang kebal terhadap senjata tajam.

Dari golongan dewasa dan tua (tokoh masyarakat) memaknai dabuih 